\title{
Crop Insurance Based on Satellite Remote Sensing: Case of Migori County, Kenya
}

\author{
Susan A. Okeyo, Galcano C. Mulaku* \\ Department of Geospatial and Space Technology, University of Nairobi, Nairobi, Kenya \\ Email: susan.okeyo@gmail.com, ^gmulaku@yahoo.com
}

How to cite this paper: Okeyo, S.A. and Mulaku, G.C. (2020) Crop Insurance Based on Satellite Remote Sensing: Case of Migori County, Kenya. Advances in Remote Sensing, 9, 1-11.

https://doi.org/10.4236/ars.202091001

Received: January 26, 2020

Accepted: March 22, 2020

Published: March 25, 2020

Copyright (อ 2020 by author(s) and Scientific Research Publishing Inc. This work is licensed under the Creative Commons Attribution International License (CC BY 4.0).

http://creativecommons.org/licenses/by/4.0/

(c) (i) Open Access

\begin{abstract}
Crop insurance, though clearly needed, has not taken root in Kenyan agriculture, and what little exists is indemnity based, meaning that a farmer is compensated only based on assessed crop damage or harvest shortfall. This is often cumbersome and expensive for the average subsistence farmer. A better approach is to use index based insurance, whereby an agreed index is computed and the farmer is compensated or not compensated depending on its value. Remote sensing technology, which is now widely available globally, provides such an index, the Normalized Difference Vegetation Index (NDVI), which is an acknowledged indicator of crop health at different stages of crop growth. This paper reports on a study carried out in mid-2019 to investigate the possibility of applying remote sensing in this way to enable crop insurance for maize farmers in Migori County, Kenya. Sentinel 2 imagery from May 2017 (taken as the insurance year) was acquired, classified and NDVI generated over the study area. An $8 \mathrm{Km} \times 8 \mathrm{Km}$ grid was overlaid and average NDVI computed per such grid cell. Similar imagery for May 2016 was acquired and similarly processed to provide reference NDVI averages. For any grid cell then, if $A_{p}$ be the insurance year NDVI and $A_{r}$ the reference NDVI, the insurance index was computed as $\left(A_{p}-A_{r}\right)$, and farmer compensation would be triggered if this value was negative. Results show that out of about 85 small holder farms in the study area, 30 would have qualified for such compensations. These results are recommended for further refining and pilot testing in the study area and similar maize growing areas.
\end{abstract}

\section{Keywords}

Crop insurance, NDVI, Remote Sensing, Migori, Kenya

\section{Introduction}

In Kenya, with an agrarian economy, crop farming constitutes a predominant 
sector of livelihood and the economy. Drought is one of the risks to crops that affect millions of small holder farmers. In Migori County, small holder farmers have experienced the ravages of drought in all forms; from mild to severe, from severe to catastrophic and from short to long-term. Whenever a severe drought occurs, small holder farmers are left severely food insecure and often resort to government and Non-Governmental Organizations (NGOs) for food aid and other assistance.

Given the numerous risk items facing crop farming such as drought, diseases and climate change impacts, there is need to come up with working solutions which go beyond the traditional risk mitigation strategies. This paper argues that remote sensing offers viable solutions to offset crop losses in such circumstances. This argument is grounded further in the findings of Towery et al. [1] who described the potential of aerial photography and remote sensing in crop hail damage assessment.

\section{Concept of Crop Insurance}

Insurance is the transfer of risk. It transfers the risk of financial losses as a result of specified but unpredictable events from an individual or entity to an insurer in return for a fee or premium [2]. Insurance is also described as an arrangement where the losses experienced by a few are extended over several who are exposed to similar risks. If a specified event occurs, the individual or entity can claim compensation or a service from the insurer. Insurance provides financial recompense for losses suffered due to incidence of unanticipated events, insured within the policy of insurance.

The concept underlying crop insurance is no different from that of other forms of insurance except that it is specific to crops just as insurance may be solely for health or property. Crop insurance generally lowers the risk faced by farmers by compensating them for damages, thus allowing them to increase their level of investment and income [2]. World Bank studies have shown that more than half of all countries support some kind of crop insurance for their farmers [3].

Crop insurance can be categorized into two major groups, namely indemnity based insurance and index based insurance [2]. The indemnity based insurance is made up of the multi-peril crop insurance, named peril and yield insurance. Other types of crop insurance are the price, income and revenue insurance which covers fluctuation in prices, yield, cost of production and farm revenue respectively. The index based insurance is made up of the area yield index, area revenue and indirect index insurance.

\section{Indemnity vs. Index Based Crop Insurance}

Indemnity based insurance (traditional) focuses on the actual loss to the farmer and claim payments are made in respect of the loss [2]. The loss is assessed from visitation to the farm by the insurance agent and the corresponding indemnity is 
calculated. Insurance coverage depends on a specific classification which could be a named peril where insurance covers only one peril or the Multi-Peril Crop insurance (MPCI) where a number of perils are covered, for example pests, floods, windstorms, fire and lightning and hailstorm damage.

Index based insurance is largely dependent on using triggers as referees for actual crop loss and loss assessments. A trigger is an index threshold below or above which payments start [4]. Payment of claims is not based on actual individual farm losses as in the case of the traditional multi-peril schemes but on deviations from the index such as rain, humidity or soil moisture. Area yield insurance is a type of insurance that measures as an index the crop yield per unit area.

\section{Remote Sensing Based Crop Insurance}

Remote sensing is the science and art of collecting information about an object without being in direct physical contact with it. The process involves interaction between incident radiation and the target of interest. Colwell defines remote sensing as "... the art, science, and technology of obtaining reliable information about physical objects and the environment, through the process of recording, measuring and interpreting imagery and digital representations of energy patterns derived from non-contact sensor systems" [5]. Remote sensing, as a monitoring system, is capable of providing three essential functions-control, warning and forecasting [6].

Satellite remote sensing is now becoming more readily available for use in precision agriculture, including crop insurance assessments. The Sentinel, Landsat and the NOAA polar-orbiting satellites carry instruments that can be used to determine crop types and conditions, and to measure crop acreage. The Advanced Very High Resolution Radiometer (AVHRR) carried on board NOAA polar orbiting satellites measures reflectance from the earth's surface in the visible, near infrared, and thermal infrared portions of the electromagnetic spectrum [7].

This spectral sensitivity makes it suitable for measuring vegetative condition and because the satellite passes overhead twice a day, it can be used to detect rapidly changing conditions, and it has been indeed used in diverse places for drought early warning and food security purposes [8]. Unfortunately, its use as a precision agriculture tool is limited because the spatial resolution of the sensor is nominally $1.1 \mathrm{~km}$ [9]. For crop insurance assessments, especially where small farms are concerned, imagery of higher resolution must be used. Landsat, Spot, Quick bird, Geo-Eye and Sentinel are all good candidates for such use; however, Sentinel, being open source and therefore freely downloadable, is particularly appealing.

\section{Crop Insurance in Kenya}

Crop insurance in Kenya has been experienced since around 2006 [10], when 
there emerged considerable interest in agricultural insurance stimulated by growing interest among international agencies willing to partner with local insurance companies to develop such insurance in respect of crops and livestock. Most of the insurance schemes of the time were indemnity based and farmers did not take them up enthusiastically. Currently there are very few instances of such crop insurance and out of the nine insurance companies that were initially involved, only two still offer agricultural insurance [11].

Some of the main reasons as to why crop insurance has not been well taken up in Kenya are:

- A small market hence high premiums.

- Lack of awareness about such insurance, hence lack of an insurance culture.

- Limited scope of cover, in terms of crops that can be insured.

- Corruption and in optimal trustworthiness, especially during assessments for payments.

The insurance law in Kenya [12] has only recently been amended to provide for index based agricultural insurance, hence this version of agricultural insurance is now expected to pick up.

\section{The Migori Study}

\subsection{The Study Area}

This study was conducted in Migori County of Kenya; specifically the study focused on two sub-counties of Migori County, namely Kuria and Suna, both of which contain about 20 villages; Figure 1 shows the area of study. Migori County

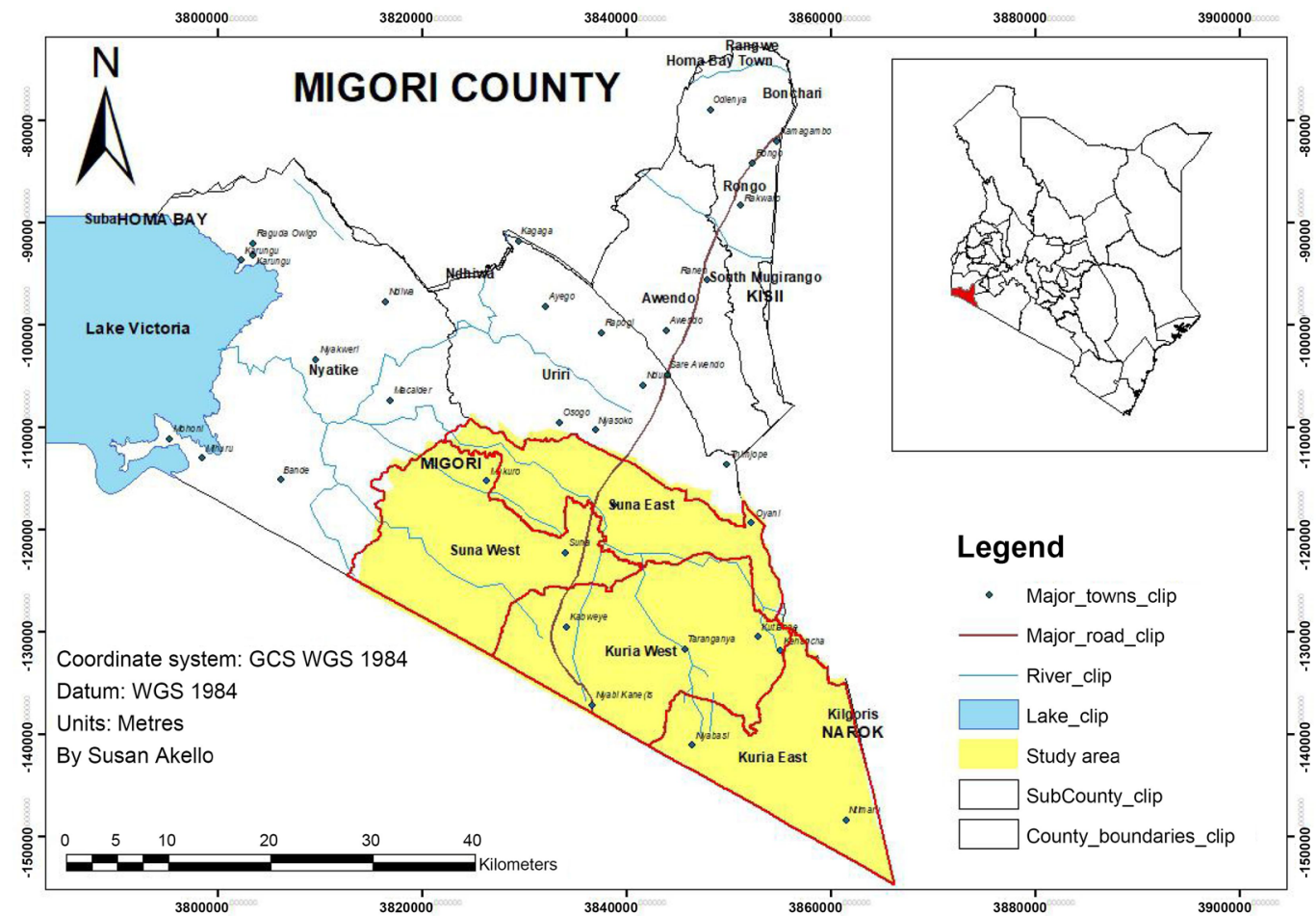

Figure 1. Map of the study area. 
(in the former Nyanza province) covers $2586 \mathrm{Km}^{2}$ and is generally flat, having mostly slopes of less than $15 \%$ gradient. The population of Migori county is approximately 1.2 million as per the 2019 population census [13] and most of them subsist on small holder farming and fishing.

Climate wise, Migori County has two main rainy seasons. The first rainy season starts in March and ends in May, this season constitutes the long rains. The second rainy season starts in September and ends in November. The driest months are between December and February and June and September. The average daily temperature is averagely a low of 24 degrees Celsius (74 F) and a high of 31 degrees Celsius $\left(87^{\circ} \mathrm{F}\right)$, [14].

\subsection{Study Objectives}

The study aimed to develop a prototype index based crop insurance system for the study area, based on remotely sensed data. This would involve; identifying a suitable remotely sensed data index to base crop insurance on; identifying and collecting relevant data and computing the indices, and making recommendations on farmer compensations based on the indices.

\subsection{Methodology}

The study targeted the maize crop, which is widely grown in the study area and which serves as both a cash crop and subsistence crop. The insurance index chosen was the Normalized Difference Vegetation Index (NDVI). 5 scenes of multispectral sentinel 2, false colour composite imagery of $10 \mathrm{~m}$ resolution and taken in May 2017 were acquired and mosaicked; the part of the mosaicked image covering the study area was then clipped out. Figure 2 and Figure 3 show the mosaicked and clipped images respectively.

May imagery was chosen for the reason that it was taken in the middle of the maize growing season when the maize is expected to be at its greenest. Reference data in the form of 75 GNSS points was acquired from the Kenya Agricultural and Livestock Research Organization (KALRO) which had carried out some ground truthing work in the area around May 2017. Six of the reference data points were used as training sites to enable subsequent image classification. Supervised classification was then carried out for two classes only, i.e. maize and other crops, and a classification accuracy of $69.3 \%$ achieved as per Table 1. Figure 4 and Figure 5 show the training sites and the classified image respectively.

Classification accuracy $=(22+30) / 75=69.3 \%$

Table 1. Accuracy assessment.

\begin{tabular}{cccc}
\hline & Maize & Other crops & Total \\
\hline Maize & 22 & 2 & \\
Other crops & 21 & 30 & \\
Total & 43 & 32 & 75 \\
\hline
\end{tabular}




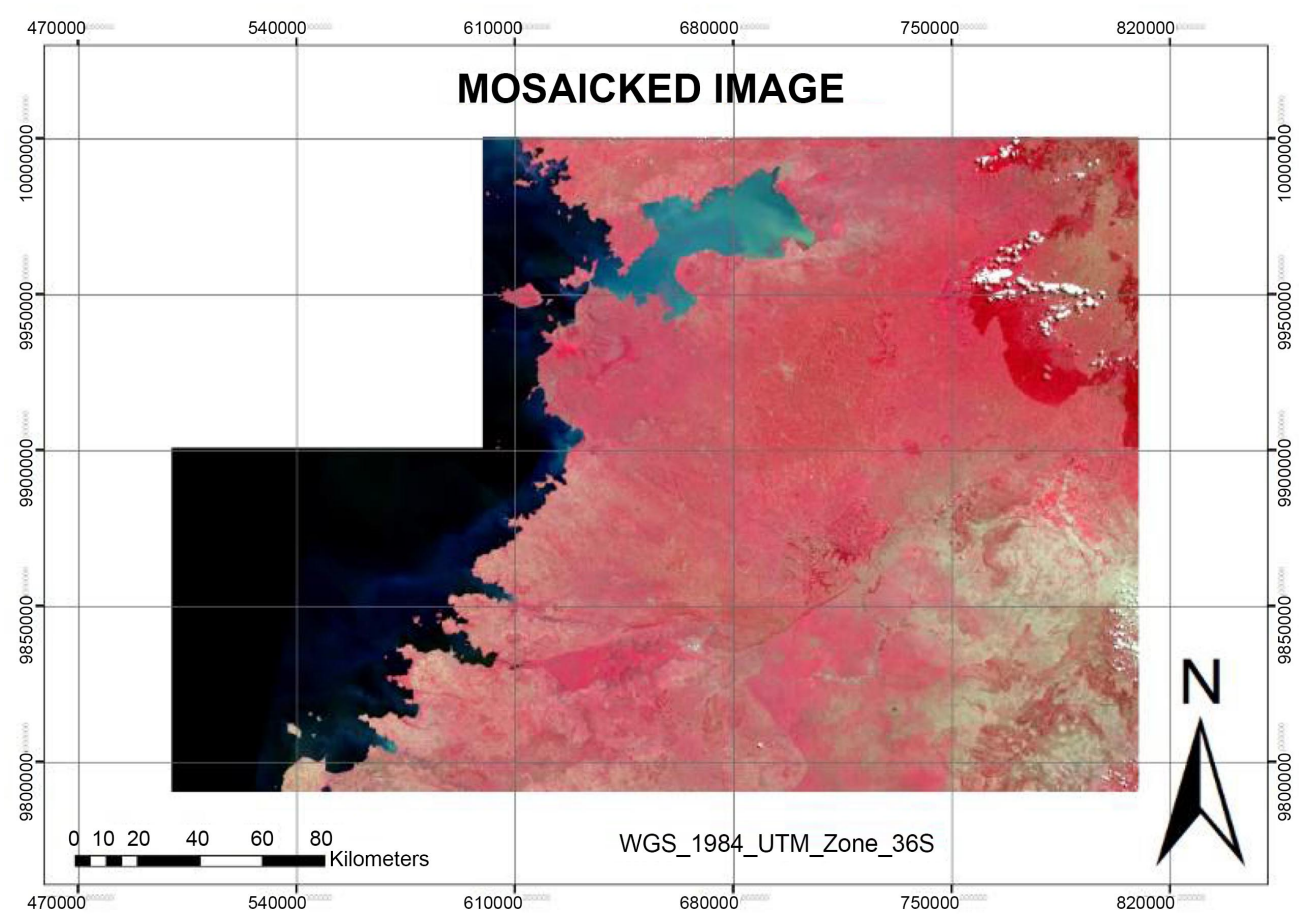

Figure 2. The Mosaicked image.

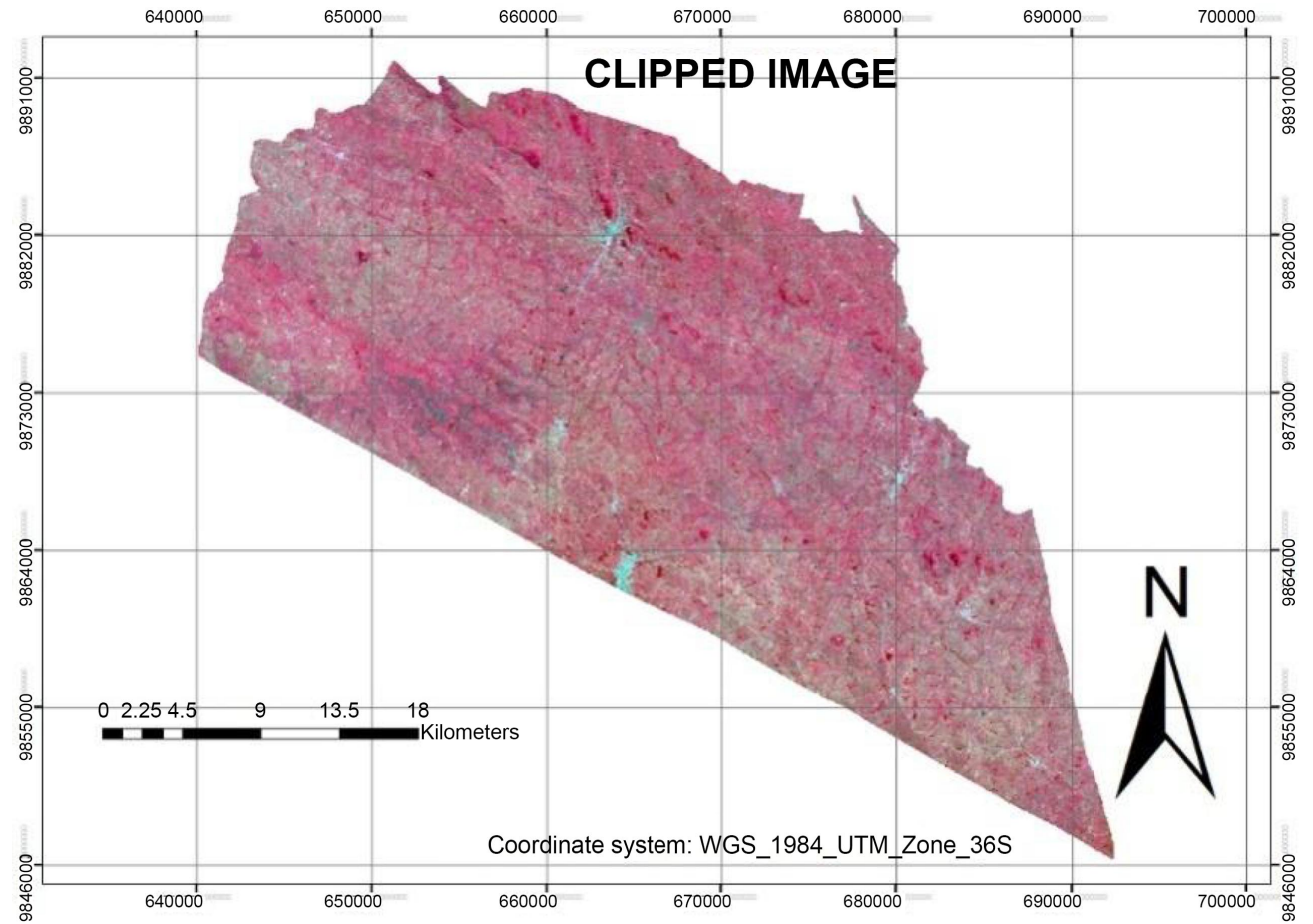

Figure 3. The Clipped image.

The classified image was then masked to highlight only the maize pixels, and NDVI values were then generated over these. An $8 \mathrm{Km}$ by $8 \mathrm{Km}$ was then superimposed over the resultant image as shown in Figure 6.

The grid provided a framework within which to compute an average NDVI 


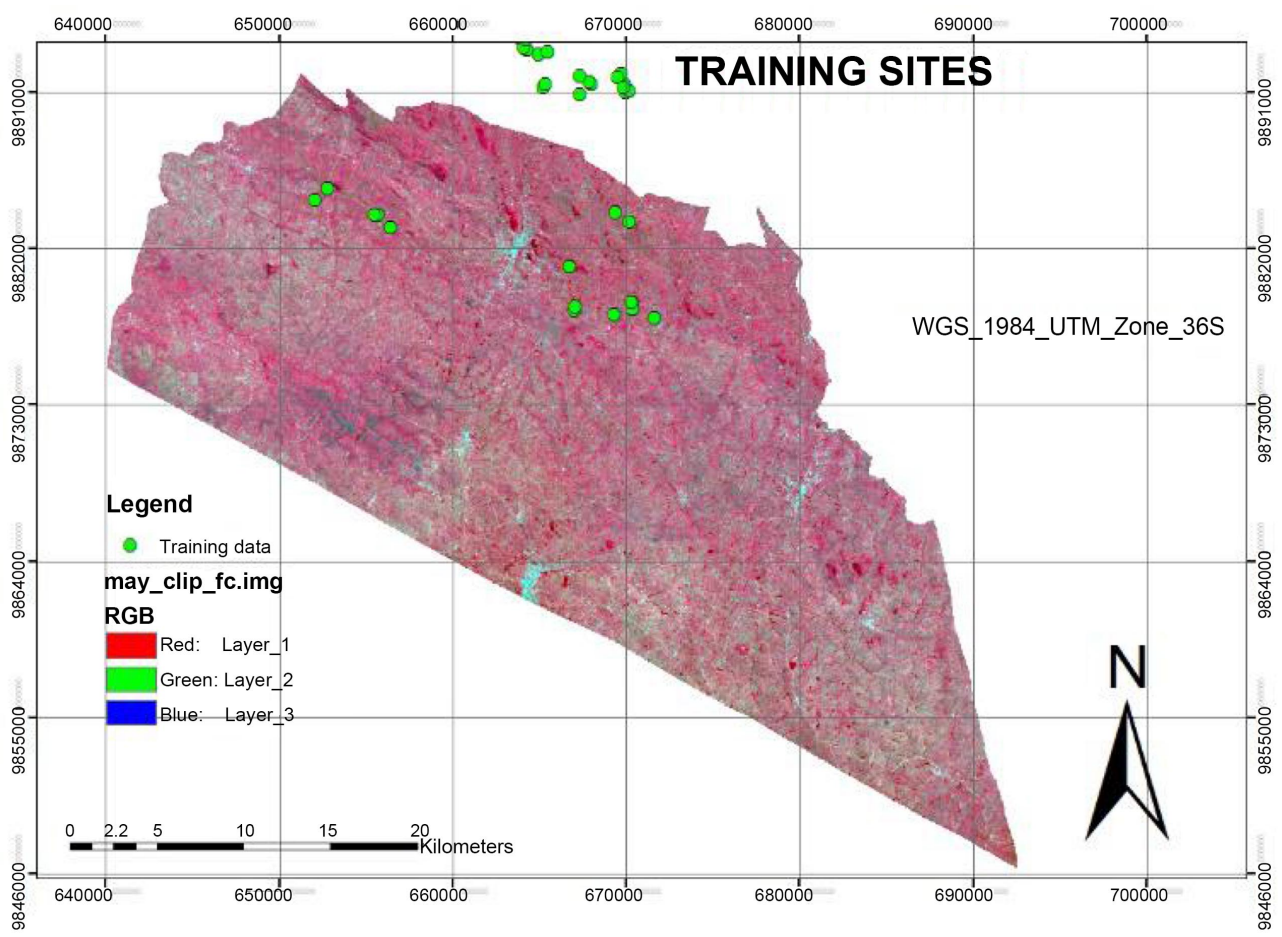

Figure 4. The Training sites.

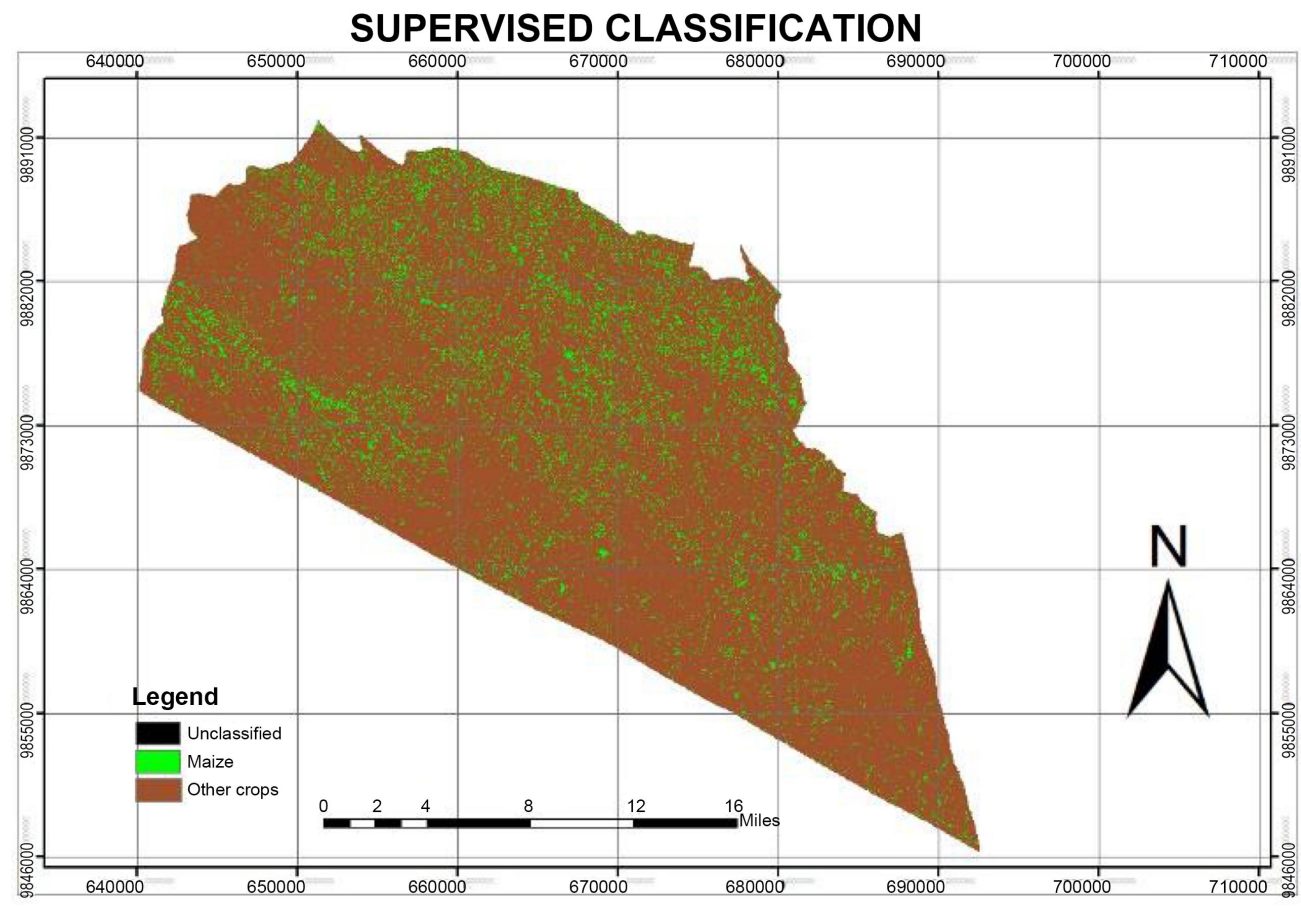

Figure 5. The classified image.

covering numerous small holder farms. Similar imagery was acquired over the study area from 2016 and similarly processed, providing NDVI averages over the same grid cells; these latter averages were taken as the reference NDVI values. For any grid cell then (and hence for all farms contained within that grid cell), if 
$A_{p}$ be the insurance year (2017) NDVI and $A_{r}$ is the reference NDVI (2016), the insurance index was computed as $\left(A_{p}-A_{r}\right)$ and farmer compensation would be triggered if the index was negative, meaning that the maize in the insurance year was less healthy than the reference and likely to lead to reduced yields and farmer losses. This is illustrated in Figure 7 and Figure 8 and this methodology is summarized in Figure 9.

NDVI GRID AVERAGES - 2017

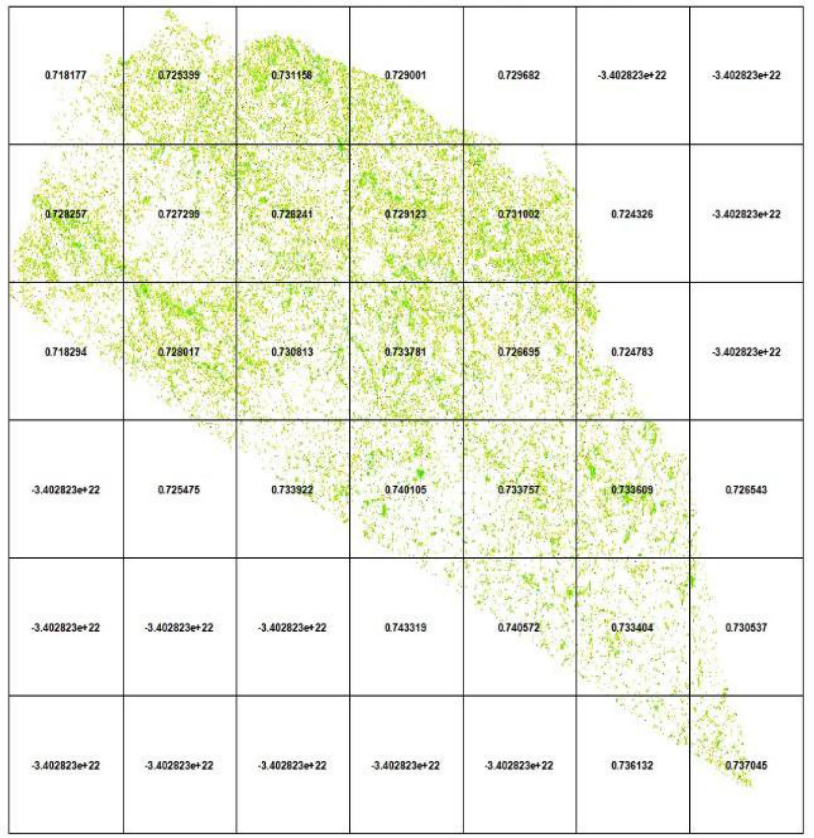

Figure 6. Grid NDVI averages-2017.

NDVI GRID AVERAGES - 2016

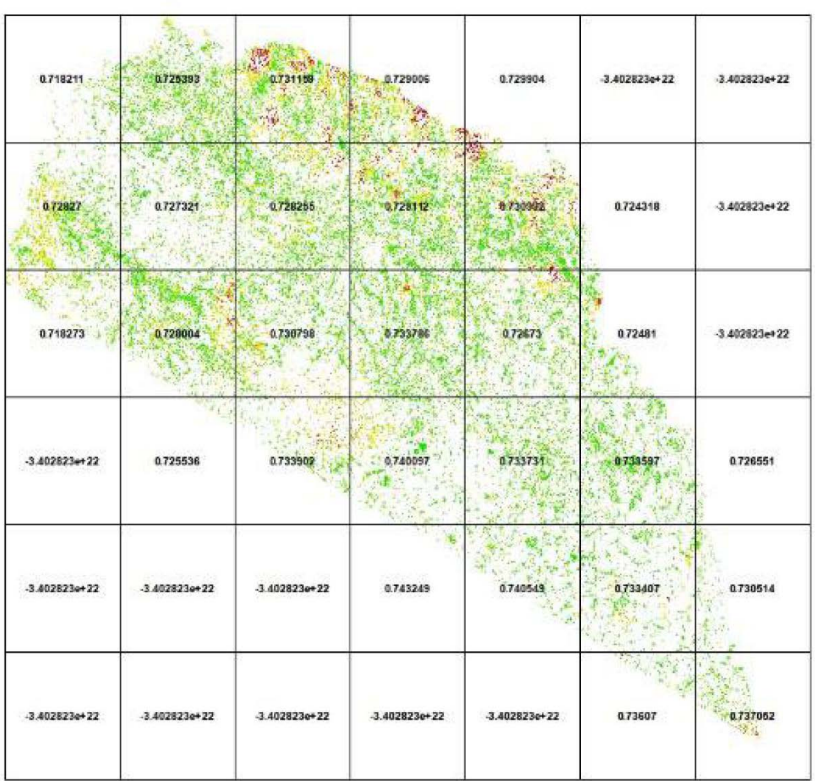

Figure 7. Grid NDVI averages-2016. 

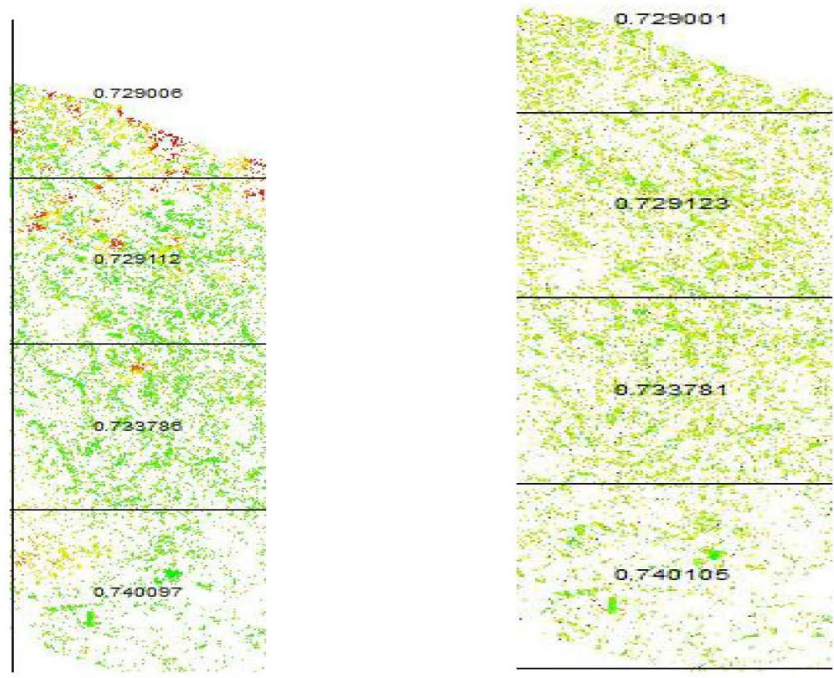

\section{6 grid samples $\left(A_{r}\right) \quad 2017$ grid samples $\left(A_{p}\right)$}

Figure 8. Grid samples.

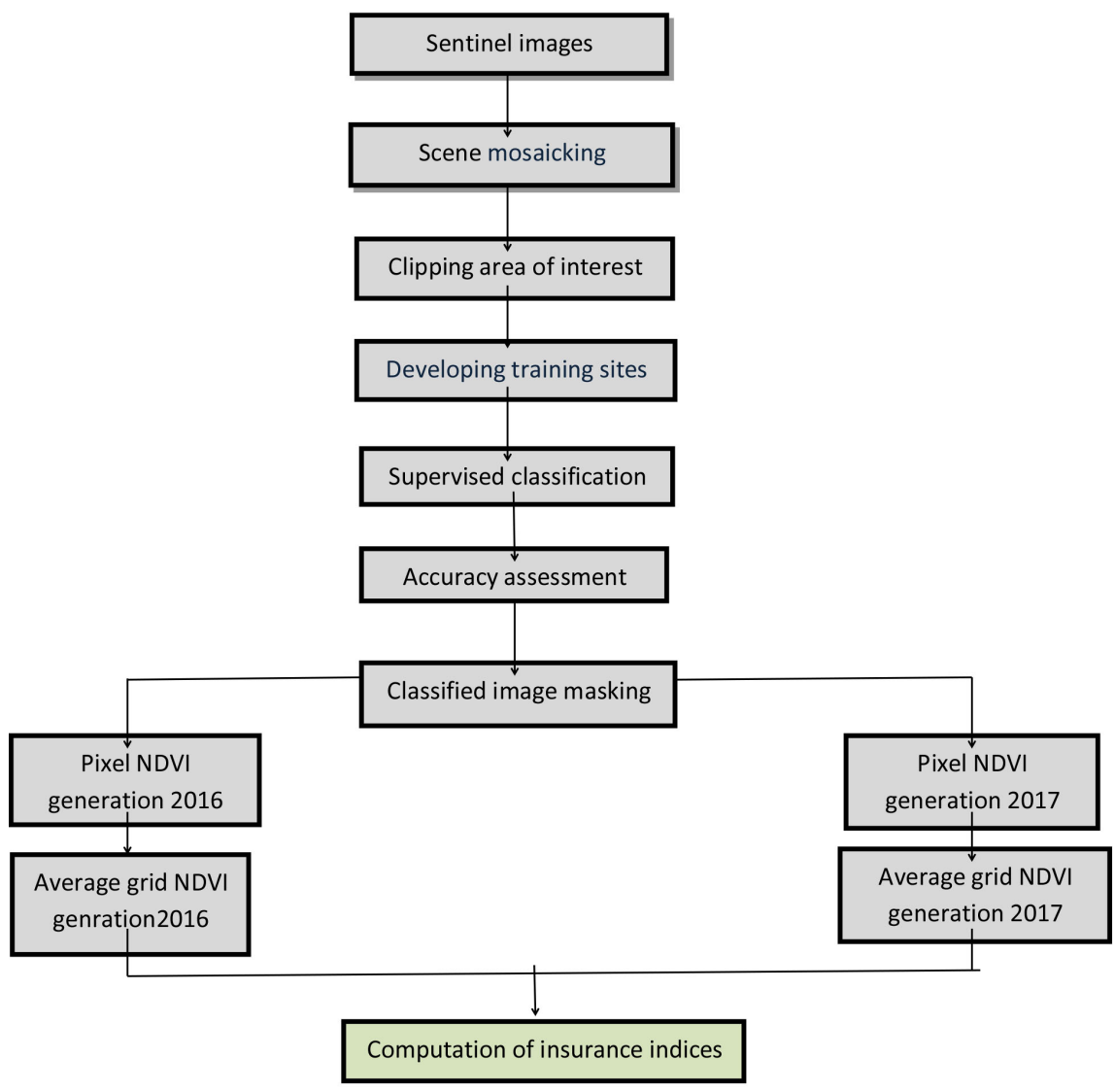

Figure 9. Methodology flow diagram.

For Grid 1: $0.729001-0.729006=-0.000005$.

Grid 2: $0.729123-0.729112=0.000011$.

Grid 3: $0.733781-0.733786=-0.000005$. 
Grid 4: $0.740105-0.740097=0.000008$.

From the grid samples used in Figure 8, the grids that would be compensated by the insurance company would be 1 and 3 since their indices are negative.

\section{Results}

An analysis of Figure 6 and Figure 7 shows that the study area is covered by approximately 17 grid cells and with each grid cell having an average of 5 small holder farms, this represents about 85 such farms. Further analysis shows that if the proposed insurance index was implemented, 30 of these farms would have qualified for compensation. Assuming, for argument purposes, that each farmer paid the same premium, this would represent an insurance loss ratio (pay outs divided by premiums) of 0.35 , very acceptable for most insurance companies [3]. Of course much more data would be needed for solid conclusion, but where such data is readily available, such as in the US, perhaps the largest market for crop insurance, analysis shows that maize insurance programs have loss ratios of typically less than 0.7 [15].

Note: The reference NDVI ought, ideally to be averaged from several years of observation as has been experienced elsewhere [16]; however this was not possible in this study since Sentinel imagery only became available in 2015.

\section{Conclusion}

This paper has documented a technique that can aid insurance companies to assess insured crops long before harvest time and hence better prepare to compensate any farmers that face crop losses. Because such compensations would be triggered by an objective index and not a human opinion, the technique would also be protective of the insured farmers. Results have shown that the technique is worthy of further refinement and pilot testing in the maize growing areas of Kenya and elsewhere.

\section{Conflicts of Interest}

The authors declare no conflicts of interest regarding the publication of this paper.

\section{References}

[1] Towery, N.G., Eyton, J.R., Changnon Jr., S.A. and Dailey, C.L. (1975) Remote Sensing of Crop-Hail Damage. Report of Research, the Country Companies, 29.

[2] Nahvi, A., Kohansal, M.R., Ghorbani, M. and Shahnoushi, N. (2014) Factors Affecting Rice Farmers to Participate in Agricultural Insurance. Journal of Applied Science and Agriculture, 9, 1525-1526.

[3] The World Bank Group (2010) Government Support to Agricultural Insurance: Challenges and Options for Developing Countries.

[4] Cole, S., Bastian, G.G., Vyas, S., Wendel, C. and Stein, D. (2012) The Effectiveness of Index Based Micro-Insurance in Helping Small holders Manage Weather-Related Risks. EPPI-Centre, Social Science Research Unit, Institute of Education, University 
of London, London, 17-18.

[5] Colwell, R.N. (1983) Manual of Remote Sensing. Second Edition, Volume I, 1-3.

[6] Lillesand, T.M. and Kiefer, R.W. (2000) Remote Sensing and Image Interpretation. John Wiley \& Sons, New York.

[7] Johnson, L., Roczen, D., Youkhana, S., Nemani, R. and Bosch, D. (1998) Mapping Vineyard Leaf Area with Multispectral Satellite Imagery. Computers and Electronics in Agriculture, 38, 33-44. https://doi.org/10.1016/S0168-1699(02)00106-0

[8] Kogan, F.N. (1998) A Typical Pattern of Vegetation Conditions in Southern Africa during El-Nino Years Detected from AVHRR Data Using Three-Channel Numerical Index. International Journal of Remote Sensing, 19, 3689-3690. https://doi.org/10.1080/014311698213902

[9] Benedetti, R. and Rossini, P. (1993) On the Use of NDVI Profiles as a Tool for Agricultural Statistics: The Case Study of Wheat Yield Estimate and Forecast in Emilia Romagna. Remote Sensing of the Environment, 45, 311-326.

https://doi.org/10.1016/0034-4257(93)90113-C

[10] Government of Kenya (2014) Agriculture Insurance Solutions Appraisal. Government of Kenya Background Report, 2.

[11] Nadia, N. (2019) Personal Communication with Manager. ICEALION Insurance Company.

[12] Government of Kenya, Insurance Amendment Act (2019)

[13] Kenya National Bureau of Statistics (2019)

[14] Kenya Meteorological Department. https://www.meteo.go.ke

[15] Woodward, J.D., Schnitkey, G.D., Sherrick, B.J., Lozano-Gracia, N. and Anselin, L. (2012) A Spatial Econometric Analysis of Loss Experience by the US Crop Insurance Program. Journal of Risk and Insurance, 79, 261-285. https://doi.org/10.1111/j.1539-6975.2010.01397.x

[16] Leblois, A., Quirion, P. and Sultan, B. (2014) Price Vs Weather Shock Hedging for Cash Crops. Ecological Economics, 10, 67-80.

https://doi.org/10.1016/j.ecolecon.2014.02.021 